\title{
PENGARUH KECERDASAN EMOSIONAL TERHADAP PENYESUAIAN PERKAWINAN PADA USIA DEWASA AWAL
}

\author{
Wening Pusparini \\ Program Studi Psikologi, Fakultas Ilmu Pendidikan, Universitas Negeri Jakarta
}

\begin{abstract}
The objective of this study is to determine the effects of emotional intelligence on marital adjustment in early adulthood. The study was conducted in South Jakarta. The population of this study is the early adulthood resident of district Pela Mampang, South Jakarta . Total population is about 500 people and the researchers took 46 people as the sample in this study because they meet the study requirement.

This study used a quantitative approach. The method used in this study is ex post facto. And the sampling technique is probability sampling.The type of probability sampling that is used in this study is purposive sampling, whereas the sampling technique depends on the criteria. Data collection technique used emotional intelligence and marital adjustment scale. The analytical techniques used in this study is normality test, linear test, and regression analysis.

Based on the study result, $F=275912, p=0.00<0.05$ (significant), suggested that there is a significant influence between emotional intelligence on marital adjustment in early adulthood. The regression equation was $\mathrm{Y}=25276$ $+0249 \mathrm{X}$. This regression suggested that if emotional intelligence is 0 , then the adjustment is positive 25,769. Regression coefficient of emotional intelligence variable is 0.249 which means if emotional intelligence scores is increased, then the marital adjustment will increase 0.249 . We obtained a positive relationship between emotional intelligence and marital adjustment because the coefficient is positive. This means that, higher emotional intelligence will result on higher marital adjustment. The influence of emotional intelligence variables on marital adjustment in early adulthood that is obtained by Adjusted R Square is 0859 which means emotional intelligence affect marital adjustment in early adulthood couples by $85.9 \%$, while the remaining percentage showed that there are other factors that influence marital adjustment on early adulthood beside emotional intelligence.
\end{abstract}

Keywords: Emotional intelligence, Marital adjustment

\section{PENDAHULUAN}

Untuk membentuk sebuah keluarga, manusia harus melalui suatu upacara perkawinan yang merupakan aspek dasar terbentuknya keluarga. Perkawinan adalah upacara pengikatan janji nikah yang dirayakan atau dilaksanakan oleh dua orang dengan maksud meresmikan ikatan perkawinan secara norma agama, norma hukum, dan norma sosial (WikiPedia Indonesia). Walaupun hidup bersama dapat menjadi alternatif untuk menggantikan perkawinan, tetapi sebagian besar manusia tetap memilih untuk menjalani perkawinan, karena perkawinan diikat dalam sebuah institusi yang legal.
Agar dapat melangsungkan perkawinan diperlukan banyak kesiapan antara lain kesiapan mental dan kesiapan fisik, selain itu adapula ketentuan batasan usia dalam menikah.

Banyaknya perkawinan dini mengakibatkan individu tidak siap dalam memikul tanggung jawab. Ketidaksiapan dalam menjalankan tanggung jawab perkawinan akan memunculkan banyak masalah dalam kehidupan berumah tangga. Ditinjau dari sudut psikologi perkembangan, ibu-ibu dan atau keluarga yang masih muda akan banyak menghadapi masalah mental dan sosial, karena memanglah pasangan muda ini, dalam banyak hal belum mempunyai persiapan yang cukup (Suprapto, 1987). Bahkan tidak sedikit masalah-masalah dalam rumah tangga akan berakhir pada perceraian. 
Permasalahan dalam keluarga yang akan mempengaruhi kondisi psikologis anak hingga terjadinya perceraian seharusnya dapat ditekan jika masing-masing pasangan memiliki penyesuaian perkawinan yang baik. Pentingnya permasalah penyesuaian perkawinan di masa awal perkawinan juga telah dikemukakan oleh salah satu tokoh psikologi perkembangan, yaitu Erikson. Erikson (1990) menjelaskan bahwa perkawinan merupakan salah satu cara logis untuk meraih intimacy pada masa dewasa muda (usia 20 - 40 tahun). Dalam rentang usia tersebut, manusia akan mengalami banyak transisi atau perubahan. Perubahan-perubahan itu yang nantinya akan menuntut dari calon orang tua suatu sikap dan sifat yang ditandai oleh adanya kematangan emosional dan sosial. Apabila perubahan-perubahan tersebut tidak disertai dengan kematangan emosional yang baik maka akan menimbulkan banyak masalah dalam kehidupan rumah tangga.

Kecerdasan emosional adalah suatu keajaiban dalam pemikiran yang memperlihatkan bagaimana keberhasilan tidak hanya ditentukan berdasarkan ukuran besar-kecilnya otak seseorang tetapi lebih kepada gagasan atau pemikiran seseorang dalam mengamati, memahami dirinya sendiri dan interaksi dengan orang lain (Schwartz, 1997). Kecerdasan emosi berperan penting dalam melakukan interaksi kehidupan sehari-hari, terlebih pada interaksi suamiistri. Kecerdasan emosi juga ditandai oleh kemampuan dalam membina hubungan dengan orang lain. Adapun kemampuan ini sangat berguna dalam membina kehidupan rumah tangga. Berdasarkan uraian diatas, mendorong peneliti untuk mengadakan penelitian tentang bagaimana pengaruh kecerdasan emosional terhadap penyesuaian perkawinan pada usia dewasa awal.

\section{II.METODE PENELITIAN}

Tipe penelitian ini adalah penelitian kuantitatif dengan desain penelitian survei. Untuk mendapatkan data yang diinginkan, maka penelitian ini menggunakan alat ukur berbentuk skala dengan model skala Likert. Adapun alat ukur yang digunakan dalam penelitian ini terdiri dari dua buah skala, yaitu skala kecerdasan emocional dan skala penyesuaian pernikahan. Metode pengumpulan data menggunakan kuesioner. Kuesioner yang akan digunakan dalam penelitian ini terdiri dari beberapa bagian, yaitu;

a) Pengantar: memberikan informasi singkat kepada subjek mengenai tujuan penelitian dan petunjuk pengisian kuesioner.

b) Form A: berisi data pribadi subjek, yaitu jenis kelamin, usia, pendidikan terakhir, pekerjaan, agama, lama menikah, jumlah dan usia anak.

c) Form B: merupakan kuesioner kecerdasan emosional yang berisi instruksi dan pernyataanpernyataan mengenai kecerdasan emosional .

d) Form C: merupakan kuesioner penyesuaian perkawinan yang berisi instruksi dan pernyataanpernyataan mengenai penyesuaian perkawinan.

Adapun populasi subjek penelitian ini adalah suami atau istri usia dewasa muda yang berdomisili di kelurahan Pela Mampang, Jakarta Selatan. Teknik pengambilan sampel yang digunakan adalah probability sampling. Jenis probability sampling yang akan digunakan adalah purposive sampling.

Alat ukur kecerdasan emosional yang digunakan dalam penelitian ini adalah adaptasi dari BarOn Emotional Quotient Inventory (BarOn EQ-i) yang disusun oleh Reuven Bar-On, Ph.D. Peneliti mengadaptasi BarOn EQ-i versi bahasa Inggris yang peneliti lihat dalam group report BarOn Emotional Quotient Inventory oleh Multi-Health Systems. Bar- 
On Emotion Quotient Inventory adalah tes menyeluruh yang dapat mengklasifikasikan setiap subjek penelitian ke dalam rentang skor EQ dan dapat digunakan dalam banyak keadaan dan situasi, termasuk dalam perusahaan, pendidikan, klinis, medis, penelitian, dan pencegahan.Pengukuran kecerdasan emosional dilakukan dengan menggunakan skala Likert yang terbagi menjadi 6 respon.

Pada penelitian ini penyesuaian perkawinan akan diukur dengan menggunakan adaptasi Dyadic Adjustment Scale (DAS). Peneliti mengadaptasi DAS dari versi Bahasa Inggris. DAS adalah sebuah alat ukur dengan 32 pernyataan laporan diri. DAS terdiri dari dyadic consensus, dyadic cohesion, dyadic satisfaction, dan affectional expression. DAS yang telah diadaptasi oleh peneliti menggunakan skala Likert dengan 6 kontinum. Setiap jawaban yang dipilih subjek akan dikonversi ke dalam bentuk angka dan diberi skor 1 hingga 6.

Teknik analisis data yang digunakan dalam penelitian ini sesuai dengan permasalahan dan hipotesis yang ingin diuji yaitu analisis data dengan menggunakan analisis Regresi Linier Sederhana. Dan sebelum melakukan pengujian hipotesis, peneliti melakukan uji asumsi yang meliputi uji normalitas data dan uji linieritas.

\section{III.HASIL PENELITIAN PEMBAHASAN}

Pada Tabel 1 dapat dilihat jumlah subjek penelitian berdasarkan jenis kelamin adalah 28 orang berjenis kelamin wanita $(60,86 \%)$ dan 18 orang berjenis kelamin pria $(39,13 \%)$, maka dapat dilihat bahwa jumlah subjek penelitian wanita lebih banyak dibanding jumlah subjek penelitian pria.

\section{1: Jenis Kelamin}

\begin{tabular}{ccc}
\hline Jenis Kelamin & F & \% \\
\hline Pria & 18 & 39,13 \\
Wanita & 28 & 60,86 \\
\hline
\end{tabular}

Tabel 2 menunjukkan persentase usia subjek penelitian yang sebagian besar berkisar antara 26-30 tahun, yaitu sebesar 63,63\%.

\section{2: Usia}

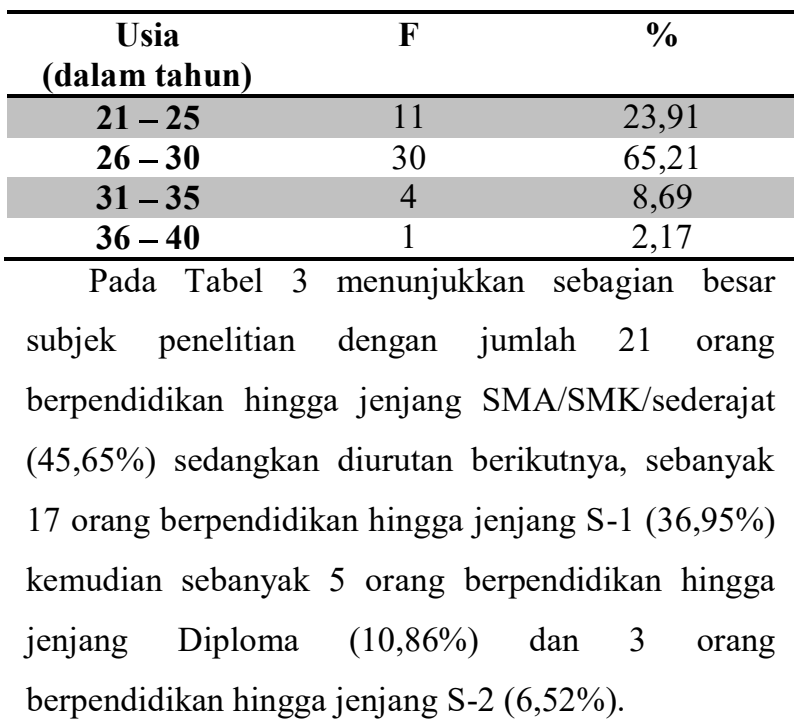

\section{3: Pendidikan Terakhir}

\begin{tabular}{ccc}
\hline Pendidikan & f & \% \\
\hline SMA/SMK/sederajat & 21 & 45,65 \\
Diploma & 5 & 10,86 \\
S-1 & 17 & 36,95 \\
S-2 & 3 & 6,52 \\
S-3 & - & 0 \\
\hline
\end{tabular}

Pada Tabel 4 dapat dilihat sebagian besar subjek penelitian bekerja sebagai ibu rumah tangga dan karyawan swasta. Kedua jenis pekerjaan ini memiliki jumlah yang lebih banyak dibanding dengan jenis pekerjaan lainnya, yakni masing-masing sebanyak 15 orang $(32,60 \%)$. 


\section{4: Pekerjaan}

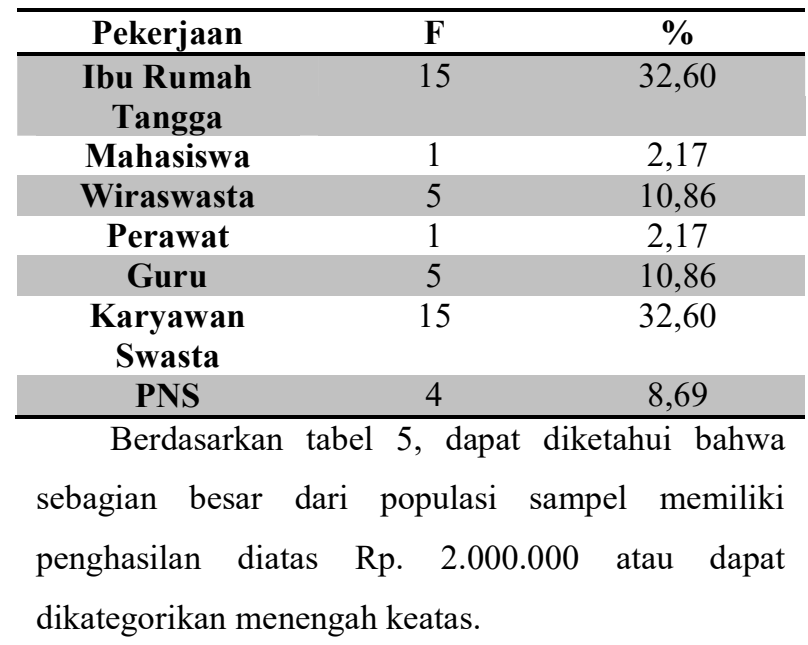

\section{5: Penghasilan}

\begin{tabular}{ccc}
\hline Penghasilan & f & \% \\
\hline$<$ Rp. 300.000 & 2 & 4,34 \\
Rp. 300.001 - Rp. & 1 & 2,17 \\
$\mathbf{5 0 0 . 0 0 0}$ & & \\
Rp. 500.001 - Rp. & 0 & 0 \\
$\quad \mathbf{8 0 0 . 0 0 0}$ & & \\
Rp. 800.001 - Rp. & 5 & 10,86 \\
$\quad \mathbf{~} .000 .000$ & & 32,60 \\
Rp. 1.000.001 - Rp. & 15 & \\
$\quad \mathbf{2 . 0 0 0 . 0 0 0}$ & & 50 \\
\hline Rp. 2.000.000 & 23 & \\
\hline
\end{tabular}

Pada tabel 6, diperlihatkan bahwa sebagian

besar subjek penelitian dalam penelitian ini beragama Islam, yakni sebanyak 44 orang $(95,65 \%)$, lainnya beragama Kristen Protestan sebanyak 2 orang $(4,34 \%)$.

\section{6: Agama}

\begin{tabular}{ccc}
\hline Agama & F & \% \\
\hline Islam & 44 & 95,65 \\
Kristen & 2 & 4,34 \\
Protestan & & \\
Katolik & 0 & 0 \\
Hindu & 0 & 0 \\
Buddha & 0 & 0 \\
\hline
\end{tabular}

Pada tabel 7, sebagian besar subjek penelitian yakni sebanyak 24 orang $(52,17 \%)$ sudah menjalani perkawinan dalam rentang waktu antara 1-2 tahun.

\section{7: Usia Perkawinan}

\begin{tabular}{ccc}
\hline $\begin{array}{c}\text { Usia Perkawinan } \\
\text { (dalam tahun) }\end{array}$ & F & $\mathbf{\%}$ \\
\hline $\mathbf{1 - 2}$ & 24 & 52,17 \\
$\mathbf{3 - 4}$ & 13 & 28,26 \\
$\mathbf{5 - 6}$ & 3 & 6,52 \\
$\mathbf{7 - 8}$ & 5 & 10,86 \\
$\mathbf{9 - 1 0}$ & 1 & 2,17 \\
\hline Pada tabel & 8, dapat dilihat subjek penelitian \\
dalam penelitian ini sebanyak 35 orang sudah \\
memiliki anak (76,08) dan sebanyak 11 orang belum \\
memiliki anak (23,91).
\end{tabular}

\section{8: Kepemilikan Anak}

\begin{tabular}{ccc}
\hline Memiliki Anak & F & \% \\
\hline Ya & 35 & 76,08 \\
Tidak & 11 & 23,91 \\
\hline
\end{tabular}

Data mengenai kecerdasan emosional diperoleh melalui kuesioner yang berupa skala kecerdasan emosional dari 80item dan diisi oleh 46 subjek penelitian. Dari hasil penelitian dan pengolahan data diperoleh skor minimum adalah 300 dan skor maksimum adalah 439. Skor rata-rata (mean) kecerdasan emosional adalah 366,85 dan standar deviasinya adalah 32,148 .

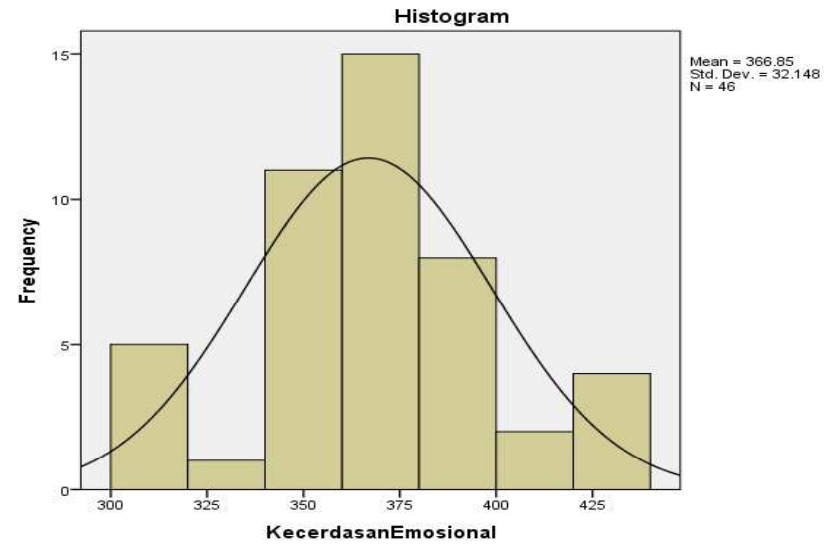

\section{Diagram Batang Kecerdasan Emosional}

Berdasarkan tabel 9, terlihat bahwa subjek penelitian yang memiliki kecerdasan emosional tinggi adalah subjek penelitian dengan kriteria 
perempuan, usia 26-30 tahun, berpendidikan S-1, pekerjaan karyawan swasta, penghasilann $>$ Rp.2.000.000, usia perkawinan antara 1-2 tahun dan sudah memiliki anak.

\section{Skor Kecerdasan Emosional Tertingi dan Terendah Berdasarkan Kriteria Tertentu}

\begin{tabular}{|c|c|c|}
\hline & $\begin{array}{c}\text { Skor } \\
\text { Kecerdasan } \\
\text { Emosional } \\
\text { Tinggi } \\
\text { (>382) } \\
\end{array}$ & $\begin{array}{c}\text { Skor Kecerdasan } \\
\text { Emosional Rendah } \\
(<352)\end{array}$ \\
\hline $\begin{array}{c}\text { Jenis } \\
\text { Kelamin }\end{array}$ & $\begin{array}{l}\text { Perempuan } \\
\text { (11 orang) }\end{array}$ & $\begin{array}{l}\text { Laki-Laki } \\
\text { (7 orang) }\end{array}$ \\
\hline Usia & $\begin{array}{c}26-30 \\
\text { tahun } \\
\text { (9 orang) }\end{array}$ & $\begin{array}{l}21 \text { - } 25 \text { tahun } \\
\text { (11 orang) }\end{array}$ \\
\hline Pendidikan & $\begin{array}{c}\text { S-1 } \\
\text { (14 orang) }\end{array}$ & $\begin{array}{c}\text { SMA/SMK/Sederaj } \\
\text { at } \\
\text { (8 orang) }\end{array}$ \\
\hline $\begin{array}{c}\text { Pekerjaa } \\
\text { n }\end{array}$ & $\begin{array}{l}\text { Karyawan } \\
\text { Swasta } \\
\text { (9 orang) }\end{array}$ & $\begin{array}{c}\text { Ibu Rumah Tangga } \\
\text { (7 orang) }\end{array}$ \\
\hline Penghasilan & $\begin{array}{c}\text { > Rp. } 2.000 .00 \\
0 \\
(10 \text { orang })\end{array}$ & $\begin{array}{l}\text { Rp.800.001- } \\
\text { Rp.2.000.000 } \\
\text { (8 orang) }\end{array}$ \\
\hline $\begin{array}{c}\text { Usia } \\
\text { Perkawinan } \\
\end{array}$ & $\begin{array}{l}1-2 \text { tahun } \\
\text { (9 orang) }\end{array}$ & $\begin{array}{l}\text { 1-2 tahun } \\
\text { (5 orang) }\end{array}$ \\
\hline $\begin{array}{c}\text { Kepemilikan } \\
\text { Anak }\end{array}$ & $\begin{array}{c}\text { Ya } \\
\text { (14 orang) }\end{array}$ & $\begin{array}{c}\text { Ya } \\
\text { (10 orang) }\end{array}$ \\
\hline
\end{tabular}

Data mengenai penyesuaian perkawinan diperoleh melalui kuesioner yang berupa skala penyesuaian perkawinan dari 32 item dan diisi oleh 46 subjek penelitian. Dari hasil penelitian dan pengolahan data diperoleh skor minimum adalah 104 dan skor maksimum adalah 131. Skor rata-rata (mean) kecerdasan emosional adalah 117,20 dan standar deviasinya adalah 8,627.

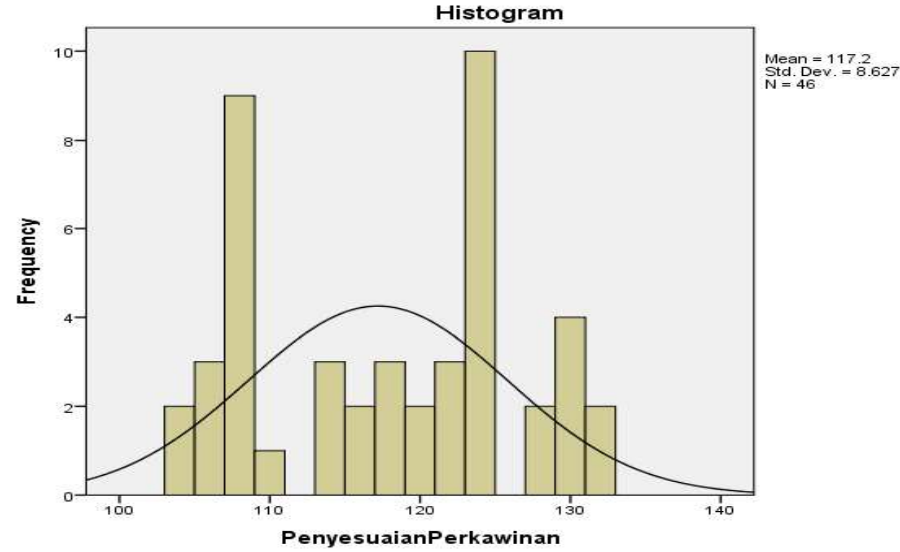

Diagram Batang Penyesuaian Perkawinan

10.Skor Penyesuaian Perkawinan Tertingi dan Terendah Berdasarkan Kriteria Tertentu

\begin{tabular}{|c|c|c|}
\hline & $\begin{array}{c}\text { Skor } \\
\text { Penyesuaia } \\
\text { n } \\
\text { Perkawina } \\
\text { n Tinggi } \\
(>125)\end{array}$ & $\begin{array}{l}\text { Skor Penyesuaian } \\
\text { Perkawinan } \\
\text { Rendah }(<\mathbf{1 1 0})\end{array}$ \\
\hline $\begin{array}{c}\text { Jenis } \\
\text { Kelamin }\end{array}$ & $\begin{array}{l}\text { Perempuan } \\
\text { (8 orang) }\end{array}$ & $\begin{array}{l}\text { Laki-Laki } \\
\text { (8 orang) }\end{array}$ \\
\hline Usia & $\begin{array}{l}31-35 \\
\text { tahun } \\
(4 \text { orang) }\end{array}$ & $\begin{array}{l}21 \text { - } 25 \text { tahun } \\
\text { (11 orang) }\end{array}$ \\
\hline Pendidikan & $\begin{array}{c}\text { S-1 } \\
\text { (8 orang) }\end{array}$ & $\begin{array}{c}\text { SMA/SMK/Sederaj } \\
\text { at } \\
\text { (11orang) }\end{array}$ \\
\hline $\begin{array}{l}\text { Pekerjaa } \\
\text { n }\end{array}$ & $\begin{array}{l}\text { Karyawan } \\
\text { Swasta } \\
\text { (4 orang) }\end{array}$ & $\begin{array}{l}\text { Ibu Rumah Tangga } \\
\text { (8 orang) }\end{array}$ \\
\hline Penghasilan & $\begin{array}{c}\text { Pp. } 2.000 .00 \\
0 \\
\text { (7 orang) }\end{array}$ & $\begin{array}{l}\text { Rp.800.001- } \\
\text { Rp.2.000.000 } \\
\text { (8 orang) }\end{array}$ \\
\hline $\begin{array}{c}\text { Usia } \\
\text { Perkawinan }\end{array}$ & $\begin{array}{l}1-2 \text { tahun } \\
\text { ( } 5 \text { orang) }\end{array}$ & $\begin{array}{l}\text { 1-2 tahun } \\
\text { ( } 6 \text { orang) }\end{array}$ \\
\hline $\begin{array}{l}\text { Kepemilikan } \\
\text { Anak }\end{array}$ & $\begin{array}{c}\text { Ya } \\
\text { (8 orang) }\end{array}$ & $\begin{array}{c}\text { Ya } \\
\text { (11 orang) }\end{array}$ \\
\hline
\end{tabular}

Berdasarkan tabel diatas, terlihat bahwa subjek penelitian yang memiliki penyesuaian perkawinan tinggi adalah subjek penelitian dengan kriteria perempuan, usia 31-35 tahun, berpendidikan S-1, pekerjaan karyawan swasta, penghasilan $>$ Rp.2.000.000, usia perkawinan antara 1-2 tahun dan sudah memiliki anak. 
Dari hasil pengujian normalitas diperoleh dari perhitungan dengan menggunakan uji Chi-Square. Dengan menggunnakan SPSS 20 diperoleh nilai $p$ pada variabel kecerdasan emosional sebesar 0,816 sedangkan nilai $\mathrm{p}$ pada variabel penyesuaian perkawinan sebesar 0,482. jika dibandingkan dengan alpha yaitu 0.05 maka kedua penelitian ini dapat dikatakan berasal dari sampel yang berdistribusi normal karena $\mathrm{p}>0.05$.

Uji linearitas dilakukan dengan menggunakan SPSS 20 dengan taraf signifikansi sebesar 0.05 . Kedua variabel dikatakan memiliki hubungan yang linear apabila hasil uji linearitasnya menunjukan hasil $\mathrm{p}<0.05$. Berdasarkan hasil perhitungan linearitas, diketahui bahwa nilai $\mathrm{p}=0.00$. Maka dapat dikatakan bahwa hubungan kedua variabel adalah linear.

Berdasarkan hasil perhitungan korelasi, dapat diketahui bahwa taraf signifikasi hitung adalah 0,000 sedangkan tingkat kesalahan (alpha) yang ditentukan adalah 0,05. Maka, taraf signifikansi hitung < tingkat kesalahan (alpha) yang ditentukan sehingga Ho ditolak yang artinya korelasi signifikan.

\section{Hasil Perhitungan Regresi}

\begin{tabular}{ll}
\hline Model & Sig. \\
\hline 1(Constant) \\
$\begin{array}{l}\text { Kecerdasan } \\
\text { Emosional }\end{array}$ \\
\hline \multicolumn{1}{c}{ Dependent variabel: Penyesuaian } \\
1. & Perkawinan $\mathrm{F}$ pada perhitungan uji linier sederhana \\
& sebesar 275.912 dengan nilai signifikansi pada \\
variabel kecerdasan emosional sebesar 0.000. Hal \\
ini menunjukan bahwa nilai signifikan kurang \\
dari $0.05(\mathrm{p}=0.00<0.05)$.
\end{tabular}

2. Nilai signifikansi pada variabel kecerdasan emosional sebesar 0.000. Hal ini menunjukkan bahwa signifikansi kurang dari 0.05 $(p=0.00<0.05)$. Sehingga dapat disimpulkan bahwa terdapat pengaruh yang signifikan antara kecerdasan emosioanal terhadap penyesuaian perkawinan pada usia dewasa awal.

3. Persamaan regresi berdasarkan data yang ada yaitu:

$$
Y=25.769+0.249 X
$$

Persamaan ini meramalkan bahwa apabila $\mathrm{X}$ diketahui nilainya, maka dapat diketahui nilai Y. Hal ini menunjukkan bahwa jika kecerdasan emosional adalah 0 , maka penyesuaian perkawinan nilainya positif sebesar 25.769 .

4. Besarnya pengaruh variabel kecerdasan emosional terhadap penyesuaian perkawinan pada pasangan usia dewasa awal diperoleh dari skor Adjusted $R$ Square yaitu 0.859 artinya kecerdasan emosional mempengaruhi penyesuaian perkawinan pada pasangan usia dewasa awal sebesar 85.9\%, sedangkan sisa persentase yang lain menunjukkan terdapat faktor lain yang mempengaruhi penyesuaian perkawinan pada usia dewasa awal selain kecerdasan emosional.

Berdasarkan hasil pengujian hipotesis yang telah dilakukan dengan menggunakan analisis regresi linier B $\quad$ Adjust R Square ${ }^{2}$ hasil yaitu terdapat .249 pengaruh yang signifikan antara kecerdasan perkawinan pada usia dewasa awal. Besarnya pengaruh kecerdasan emosional terhadap penyesuaian perkawinan adalah $85.9 \%$. Hal ini menunjukkan salah satu faktor yang mempengaruhi penyesuaian perkawinan pada usia dewasa awal adalah kecerdasan emosional. Hasil hipotesis tersebut menunjukkan bahwa terdapat pengaruh positif, yang menjelaskan bahwa jika tingkat kecerdasan emosional semakin tinggi maka penyesuaian perkawinan pada usia dewasa awal juga 
Jurnal Penelitian dan Pengukuran Psikologi

Vol. 1, No.1, Oktober 2012

tinggi. Apabila tingkat kecerdasan emosional rendah maka penyesuaian perkawinan juga ikut rendah.

\section{IV.KESIMPULAN}

Penelitian ini mengkaji masalah pengaruh antara kecerdasan emosional terhadap penyesuaian perkawinan pada usia usia dewasa awal. Berdasarkan hasil penelitian, terdapat pengaruh yang signifikan antara kecerdasan emosional terhadap penyesuaian perkawinan pada usia dewasa awal. Pengaruh kecerdasan emosional terhadap penyesuaian perkawinan sebesar $85,9 \%$ sedangkan sisanya dipengaruhi oleh faktor lain.

\section{DAFTAR PUSTAKA}

Agustian, Ari Ginanjar. (2001). Rahasia Sukses Membangun Kecerdasan Emosi dan Spiritual (ESQ, Emotional Spiritual Quotient). Jakarta: Arga.

Anastasi, A. (1982). Psychological Testing. $7^{\text {th }}$ edition. New York: MacMillan Publishing Co., Inc.

Andaninggar, A. (2009). Hubungan antara pilihan genre buku fiksi favorit dan kecerdasan emosional pada dewasa muda. Skripsi (tidak diterbitkan). Depok: Fakultas Psikologi Universitas Indonesia.

Anjani, Cinde \& Suryanto. (2006). Pola penyesuaian perkawinan pada periode awal. Jurnal Ilmiah. Semarang: Universitas Airlangga.

Anonim. (2010). Modul Pelatihan SPSS Statistik. Pusat Pengembangan Teknologi Informasi Universitas Negeri Jakarta, h.22-64.
Azwar, Saifuddin. (2008). Penyusunan Skala Psikologi. Yogyakarta: Pustaka Pelajar.

Bharwaney,Geetu., Bar-On, Reuven., and MacKinlay, Adele (2007). EQ and the Bottom Line: Emotional Intelligence Increases Individual Occupational Performance, Leadership and Organisational Productivity. United Kingdom: Ei World.

Brown, Shelley and Ivonne. (2004). A review of the emocional intelligence literature and implications for corrections. Canada: correctional service of Canada.

Emzir. (2007). Metodologi Penelitian Pendidikan. Jakarta: Rajawali Press.

Goleman, Daniel. (2002). Mengapa EI lebih penting daripada IQ. Jakara: PT.Gramedia Pustaka Utama.

Goleman, Daniel. (2003). Kecerdasan Emosi untuk Mencapai Puncak Prestasi, Jakarta: PT. Gramedia Pustaka Utama.

Gottman, John. (2001). Kiat-kiat Membesarkan Anak yang Memiliki Kecerdasan Emosional (terjemahan). Jakarta : PT Gramedia Pustaka Utama.

Hurlock, E.B. (2002). Psikologi Perkembangan $5^{\text {th }}$ edition. Jakarta: Erlangga.

Safitri, A. (2008). Hubungan antara resolusi konflik dengan penyesuaian perkawinan pada dewasa muda. Skripsi (tidak diterbitkan). Depok: Facultas Psikologi Universitas Indonesia.

Sampoerno, Does dan Azwar, Azrul. (1987). Perkawinan dan Kehamilan pada wanita usia 
muda "Early Age of Marriage and Pregnancy among Women in Indonesia". Jakarta: Ikatan Ahli Kesehatan Masyarakat Indonesia (The Indonesian Public Health Association).

Santrock, J. W. (1995). Life - Span Development Perkembangan Masa Hidup. Jakarta: Penerbit Erlangga.

Saphiro, Lawrence. E. (1997). Mengajarkan Emotional Intelligence pada Anak. Jakarta : PT Gramedia Pustaka Utama.

Spanier, Graham. (1976). Measuring Dyadic Adjustment: New Scale for Assessing the Quality of Marriage and Similar Dyads. The Pennsylvania State University.
Sri, Lanawati. (1999). Hubungan Antara Emotional Intelligence dan Intelektual Quetion dengan Prestasi Belajar Siswa SMU.Tesis Master : Fakultas Psikologi Universitas Indonesia.

Sukardi. (2003). Metodologi Penelitian Pendidikan. Yogyakarta: Penerbit Bumi Aksara.

Wahyuningsih, Hepi. (2005). Penyesuaian Perkawinan Pasangan Suami-Istri Dewasa Muda Ditinjau dari Kecerdasan Emosional dan Umur Perkawinan. Jurnal Ilmiah. Yogyakarta: Universitas Islam Indonesia.

3007 istri di Jakarta Selatan gugat cerai suami. (12 Juni 2012). Kompasiana. Diambil dari http://lifestyle.kompasiana.com/urban/2012/06 /12/3007-istri-di-jak-sel-gugat-cerai-suami/ 